\title{
RECONCILING CUSTOMARY LAW AND CULTURAL PRACTICES WITH HUMAN RIGHTS IN UGANDA
}

\author{
Jamil Ddamulira Mujuzi \\ Professor of Law, Faculty of Law \\ University of the Western Cape
}

SUMMARY

Customary law has been part of Ugandan law for many years. Section 2 of the Local Council Courts Act, 2006 defines "customary law" to mean "the rules of conduct established by custom and long usage having the force of law and not forming part of the common law nor formally enacted in any legislation". Ugandan courts have explained the relationship between customary law and other laws. In 1995, Uganda adopted a constitution that includes, among other things, a bill of rights that prohibits discriminatory and degrading laws and customs. This was informed during the making of the Constitution by the arguments of many Ugandans that discriminatory and degrading customary practices and laws should be abolished by the Constitution. In this article, the author illustrates the steps that have been taken by the drafters of the Constitution, Parliament (through legislation) and courts to outlaw discriminatory and degrading cultural practices. The author recommends ways in which some of these measures could be strengthened.

\section{INTRODUCTION}

Customary law has been part of Ugandan law for many years and was

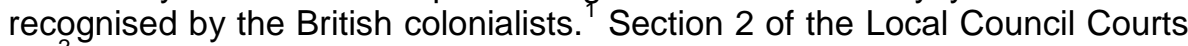
Act $^{2}$ defines "customary law" to mean "the rules of conduct established by custom and long usage having the force of law and not forming part of the common law nor formally enacted in any legislation". In Magbwi v MTN (U) Limited, ${ }^{3}$ the High Court, without referring to the Local Council Courts Act, explained customary law as follows:

\footnotetext{
During colonialism, "[a] system of native courts operated alongside the courts administering received law. They were established in a hierarchy corresponding to the local government administrative structure, the lowest at sub-county level and the highest at district level. They were composed of both chiefs and unofficial members. In criminal cases the courts had power to order sentences of up to six months imprisonment. Both county and district native courts had original and appellate jurisdiction. Appeals lay from district native courts to the district commissioner and then to the High Court. The High Court could also try a case to which customary law applied as a court of first instance" (Report of the Constitutional Commission (1992) par 17.10. See also par 17.140). 
"Customary law ... concerns the laws, practices and customs of indigenous peoples and local communities. It is, by definition, intrinsic to the life and custom of indigenous peoples and local communities. What has the status of 'custom' and what amounts to 'customary law' as such will depend very much on how indigenous peoples and local communities themselves perceive these questions, and on how they function as indigenous peoples and local communities. Defining or characterising 'customary law' typically makes some reference to established patterns of behaviour that can be objectively verified within a particular social setting or community which is seen by the community itself as having a binding quality. Such customs acquire the force of law when they become the undisputed rule by which certain entitlements (rights) or obligations are regulated between members of a community."

The nature of customary law and its relationship with other laws in Uganda are explained in the following terms by the Constitutional Commission:

"The judiciary administers a system of laws which in Uganda includes the Constitution, statutes enacted by Parliament, common law principles derived from English law and customary law. Customary law is essentially local in character having evolved from the traditions of the varied tribes of Uganda. Although almost entirely unwritten, customary law continues to provide a primary reference for the regulation of the lives of most Ugandans in respect of basic activities and relationships including family life and property rights, land and livestock. It is recognized as enforceable law, particularly in the field of civil disputes, provided it is not in conflict with statutory law and not repugnant to justice and equity."

In Dima Domnic Poro $v$ Inyani, ${ }^{6}$ the High Court highlighted the central role customary law plays in the lives of many Ugandans, especially those in rural areas. The court observed:

"Customary laws and protocols are central to the very identity of many local communities. These laws and protocols concern many aspects of their life. They can define rights and responsibilities on important aspects of their life, culture, use of and access to natural resources, rights and obligations relating to land, inheritance and property, conduct of spiritual life, maintenance of cultural heritage, and many other matters. Customary practices of inheritance impact directly on the right to culture (of course excluding rules which treat people unequally or which limit other rights in a way which is unreasonable and goes against the spirit of the rest of the fundamental rights). In many traditional communities in a rural setting, a majority of the people identify with customary laws of inheritance and conduct their lives in conformity with them."

The court, after highlighting the tension between customary law and written law, ${ }^{8}$ added:

"The crucial consequence of such strict application [of written law] is that it creates tensions between the legal and customary transmission of rights in land, in respect of land governed by customary law. In the rural traditional community setting, interwoven into all interactions between family and

4 Magbwi v MTN (U) Limited supra 10. See also Odongo v Ojera (Civil Appeal No. 0053 of 2017) [2019] UGHCLD 1 (21 February 2019).

5 Report of the Uganda Constitutional Commission (1992) par 17.2.

6 (Civil Appeal No. 0017 of 2016) [2017] UGHCCD 154 (30 November 2017).

7 Dima Domnic Poro v Inyani supra 9.

8 Dima Domnic Poro v Inyani supra 9. 
community members are the dual concepts of shame and respect. Shame and respect create the parameters for interactions and create the framework for customary law. One reason that customary law is more often used than written law in relation to family and community relations is that it embodies the notions of shame and respect. Where conflicts exist between customary law and written law, customary law generally prevails in the villages because written law often fails to reflect the reality of the villagers' lives. Enactments which disregard the value and strength of these cultural norms are barely embraced. Without an understanding of these fundamental norms of behaviour, such enactments and the decisions based on them quickly become irrelevant. In the result, legal rules do not automatically change or override customary law. Rather, legal rules support change and the desire for change, but real change only occurs when it is no longer shameful or disrespectful to behave in the manner mandated by the legal rule. The better option therefore is to make determinations of transmission of rights to land held customarily within a framework of interdependence between customary law and statutory law rather than exclusively on the basis of statutory law. The struggle of maintaining customary law as a legal system while adhering to the expectations of statutory law and developments in the modern world reflects another battle: that between an idyllic world and the reality of traditional societies."

The fact that customary law (sometimes referred to as traditional law),$^{10}$ is not codified means that, inter alia, it is difficult for some people to know what it is exactly. As one Constituent Assembly delegate submitted during the making of the Ugandan Constitution,

"[t]he dual legal system in Uganda where customary and statutory laws are practiced simultaneously are confusing. Customary laws which are often discriminatory against women take precedence over our statutory laws because the latter is always shrouded in mystery."

According to section 46 of the Evidence $A c t,{ }^{12}$ a court may call an expert to give an opinion on the existence of a custom. ${ }^{13}$ There have been cases in which courts have called expert witnesses to give evidence on the existence or otherwise of a customary practice. ${ }^{14}$ In some cases, courts have, in the absence of evidence, declined to express an opinion on the existence or

Dima Domnic Poro v Inyani supra 10.

10 Dima Domnic Poro v Inyani supra 10. See also Proceedings of the Constituent Assembly (1994-1995) 1308.

1 Proceedings of the Constituent Assembly 869

12 Chapter 6 of the Laws of Uganda.

13 S 46 provides that "[w]hen the court has to form an opinion as to the existence of any general custom or right, the opinions as to the existence of that custom or right, of persons who would be likely to know of its existence if it existed, are relevant".

Explanation - The expression "general custom or right" includes customs or rights common to any considerable class of persons." For the interpretation of $s 46$, see Odongo $v$ Ojera supra; Hadadi Mohamed Rajab v Muzamil Mohamed Rajab (Civil Suit No. 188 of 2015) [2019] UGHCFD 48 (26 August 2019) par 14; The Administrator General v George Mwesigwa Sharp (Civil Appeal No 6 of 1997) [1998] UGCA 14 (19 November 1998).

14 Musamali v Musamali (HCT-04-CV-CA-0001/2001) [2006] UGHCFD 1 (4 April 2006); Wonaku v Makoba (Civil Revision No. 0004-2012) [2012] UGHC 91 (10 May 2012); (The Court dealt with the issue of dowry as one of the aspects of valid Kigisu customary marriage). 
otherwise of a custom or cultural practice. ${ }^{15}$ However, the High Court held that no such evidence is needed where "the culture or custom has gained such notoriety as to be taken judicial notice of". ${ }^{16}$ For example, in Uganda $v$ Asiimwe, ${ }^{17}$ the High Court took judicial notice of "the generosity and accommodative nature of the Ugandan culture". ${ }^{18}$ Uganda has many ethnic groups and some customary practices found in one group do not exist in others. ${ }^{19}$ In other words, it is not possible to talk of a single body of customary law. It is therefore important that Ugandans respect each other's customary practices. ${ }^{20}$ Even before colonialism, there were sanctions for disobeying established customs and traditions. ${ }^{21}$ The recognition of customary law by the colonialists was not absolute. Customs were recognised on condition that they were not repugnant to natural justice (the so-called repugnance clause). One of the reasons that Ugandans detested the judicial system introduced by the British colonialists was that

"the received law remained foreign to the majority of people. It was not (and is

still not) in harmony with the norms and customs of African peoples."

After independence, the "whole [foreign law] legal system should have been transformed to suit our [Ugandan] own culture, norms and customs." ${ }^{23}$ This system had to be replaced by laws and institutions that recognise the customs of Ugandans. One of the ways in which this objective was to be achieved was through adopting a constitution that, not only recognised customary law, but also outlawed oppressive customary or cultural practices. It is against this background that the Constitution includes many provisions that are relevant to the issue of customary law.

The purpose of this article is to highlight the measures taken, and being taken, in Uganda to abolish oppressive customary and cultural practices. These measures are: the adoption of a constitution that prohibits oppressive customary practices; the enactment of legislation prohibiting some customary practices; petitioning courts to declare some customary practices unconstitutional; and courts, on their own, declaring some customary practices unconstitutional. The author discusses the issue of courts with jurisdiction over customary law matters and also highlights some of the challenges facing the government in enforcing the relevant legislation. Recommendations on how such laws could be better enforced are made.

15 In Mugisha v Rusiisi (HCT) [2013] UGHCCD 99 (25 July 2013), the court declined to rule that there is a culture of Banyankole being attached to their cows; and see Katakuwange Mulwanyi Michael $v$ Mulwanyi Michael (Civil Appeal No 41 of 2008) (Civil Appeal No 41 of 2008) [2010] UGHC 114 (29 September 2010) on the existence of a customary lease.

16 Mugisha v Rusiisi supra 5.

17 (High Court Criminal Session Case No. 143 of 2001) [2002] UGHCCRD 11 (2 December 2002).

18 Uganda v Asiimwe supra 3.

19 Proceedings of the Constituent Assembly 2362.

20 Proceedings of the Constituent Assembly 2313 and 2095.

Report of the Constitutional Commission par 28.16.

22 Report of the Constitutional Commission par 19.13.

23 Report of the Constitutional Commission par 17.75. 


\section{THE CONSTITUTIONAL APPROACH TO ABOLISHING OPPRESSIVE CUSTOMARY PRACTICES}

As mentioned above, the Ugandan Constitution recognises customary law but also prohibits oppressive customary practices. It is imperative to refer briefly to the drafting history of the Constitution to have an understanding of the background to the inclusion of the relevant provisions in the Constitution. An understanding of this history promotes an appreciation of the context in which Ugandans have approached the issue of the constitutionality or otherwise of some customary practices.

\section{Customary law and practices and the drafting history of the Ugandan Constitution}

In the late 1980s, Uganda embarked on a process of enacting a new constitution to replace the 1967 Constitution that had been substantially based on the one adopted at independence without public participation. In order to ensure that as many people as possible participated in the constitution-making process, the government established the Constitutional Commission. ${ }^{24}$ The Commission's mandate was to:

"study and review the [1967] Constitution with a view to making proposals for the enactment of a national Constitution that will, inter alia ... (ii) establish a free and democratic system of government that will guarantee the fundamental rights and freedoms of the people of Uganda."

The Commission visited many parts of Uganda to collect people's views on the issues to be addressed in the new Constitution. It also received submissions from different people, institutions and organisations. ${ }^{26}$ One of the issues addressed in the Commission's report is customary law or practices. The report shows that even before colonialism, customary law recognised some rights such as the right to life ${ }^{27}$ and the right to equality. ${ }^{28}$ Customary law also regulated the manner in which wars were waged and conducted. ${ }^{29}$ Some of the people who made submissions to the Constitutional Commission were very critical of the fact that the legal system

24 Uganda Constitutional Commission Statute No. 5 of 1988.

25 Report of the Constitutional Commission par 4.

Report of the Constitutional Commission 8-12.

Report of the Constitutional Commission par 7.18(a).

Report of the Constitutional Commission par 7.18(b).

29 Report of the Constitutional Commission par 7.18(d): "Traditional society had commonly developed humanitarian rules in war. Laws and customs often spared lives of children, women and the disabled, the sick and the old during any inter-tribal fighting. War was undertaken between the able-bodied men of different tribes. Women and children would be taken as part of the war loot but would normally not be killed or maimed. From their condition of captured people, prisoners of war could gradually be assimilated into the victorious society and if they proved persons of quality they could often climb the ladder of social leadership to very high positions." 
introduced by the British did not recognise some customary law. The Commission reported that people were concerned that

"the foreign nature of the law relates to the failure of much of the statute law to take into account Ugandan cultural norms. People raised special concerns about particular laws such as those on marriage, divorce, adoption etc. which they said do not conform with the customs and norms of the African culture. As such, laws have remained foreign to the people, many of whom have continued observing their own culture and ignored the received law."

Although Ugandans were of the view that the new Constitution should recognise customary law, they wanted oppressive customary practices abolished. For example, on the issue of the relationship between some customary practices and human rights, especially women and children's rights, the Commission reported:

"Women are discriminated against by oppressive and old fashioned traditions, customs and practices in the various tribes and communities which tend to reduce them to the status of children. They are concerned about laws which discriminate against them in several aspects: property ownership, marriage, separation, divorce, custody of children and inheritance. They are concerned about negative male attitudes, formed through the centuries, which minimise the importance of women and ignore their full dignity, ability and contribution to society. They are concerned about their roles in marriage and family which have been taken for granted and not properly recognized or remunerated. Society has not enabled them to realise their full potential for their own development and that of the nation. They are also concerned about religious bodies and cultural institutions which deny them equality with men.

The Commission also reported that some people were concerned that some men invoked customary practices to deprive widows of property acquired during marriage ${ }^{32}$ and that "[t]he right to marry and form a family has often been interfered with by tribal customs on grounds of race, tribe, creed or socio-economic status". ${ }^{33}$ The Commission also reported that many people were of the view that the Constitution should recognise the right to culture. ${ }^{34}$ The Commission indicated that the majority of the submissions were opposed to the argument, made by some people in their submissions, that

"no limitations [should be put] on the right to culture, each society or tribe being seen as the best judge of its own culture and the practices or customs which it exhibits."

This view was opposed because, inter alia, cultural practices were dynamic and some were contrary to human rights. ${ }^{36}$ The Commission concluded by outlining the principles that people suggested should be used in determining whether or not a cultural practice should be retained:

\footnotetext{
Report of the Constitutional Commission par 17.27.

Report of the Constitutional Commission par 7.64.

Report of the Constitutional Commission par 7.65.

Report of the Constitutional Commission par 7.73(d).

Report of the Constitutional Commission par 7.132.

Report of the Constitutional Commission par 7.132.

Report of the Constitutional Commission par 7.133.
} 
"(a) No cultural practice should dehumanise, discriminate or offend against the human rights and freedoms of the individual, whether man or woman, child or adult; (b) No practice or custom should threaten or weaken nation-building; (c) No practice should be anti-development, anti-morality or anti-human equality or dignity; (d) No practice should be imposed by force on any member of society or section of that society."

Against that background, the Commission recommended that the new constitution should provide the following on the issue of the right to culture:

"(a) Every person should have the right to enjoy, practise, profess, maintain and promote any culture, language, tradition or creed or religion but subject to the provisions of the Constitution and to the condition that the rights so protected do not offend against the rights of others or the national interest. (b) All customary practices which dehumanise, discriminate or are injurious to the integral well-being of a person should be prohibited. All cultural practices and traditions should be under effective control of the Constitution and the laws of the country. They should not go against any provisions of the Constitution. (c) Culture should always develop to fit smoothly into the contemporary values and aspirations of society. It should recognise and respect especially the rights and equality of women and the rights of children and other sections of society.

It is against that background that the Commission recommended that the new constitution should recognise customs and traditions on condition that they are not oppressive and in particular that they were not contrary to the rights in the Bill of Rights. ${ }^{39}$ In particular, the Commission recommended that "[l]aws, cultural practices and customs which are against the dignity, equality, welfare or interests of women should be prohibited by the new Constitution, the laws of the country and the relevant cultural groups in the country". ${ }^{40}$ The Commission also highlighted a number of oppressive customary practices and called for their abolition. These included relatives dispossessing widows and children of their property upon the death of the husband or father, ${ }^{41}$ and widow inheritance. ${ }^{42}$ Apart from enacting the Constitution to abolish oppressive customary practices, the Commission also called upon the Uganda Law Reform Commission to repeal or amend laws that criminalised "various customary legal systems of the country." ${ }^{.43}$ It also recommended the establishment and/or re-establishment of the institution of traditional leaders "in accordance with the respective cultures, customs traditions, wishes and aspirations of the people concerned and subject to the provisions of the new Constitution". ${ }^{44}$ However, traditional leaders were not to reintroduce dehumanising and oppressive cultural practices. ${ }^{45}$ The Commission added that the law establishing traditional leaders "should not interfere in cultural practices that are not against public interest or the ideals

37 Report of the Constitutional Commission par 7.134.

38 Report of the Constitutional Commission par 7.135.

39 Report of the Constitutional Commission par 7.141(a).

40 Report of the Constitutional Commission par 7.141(e).

Report of the Constitutional Commission par 17.180.

Report of the Constitutional Commission par 17.180.

Report of the Constitutional Commission par 17.197(d).

Report of the Constitutional Commission par 19.115(b). See also par 19.128.

Report of the Constitutional Commission par 19.129. 
of the Constitution" especially the Bill of Rights. ${ }^{46}$ The Commission concluded that customary land tenure should be maintained. ${ }^{47}$

The Commission's report was discussed by the Constituent Assembly whose mandate was to come up with the final constitution that would be adopted. The issues of customary law generally and customs in particular, as expected, also featured in the Constituent Assembly debates. The delegates submitted that although Uganda had to ensure human rights and freedoms were promoted and protected, they should not erode "our customs and traditions". ${ }^{48}$ Such positive customs included male circumcision (practised by some communities), ${ }^{49}$ parents giving a piece of land to a woman before she gets married (practised by two ethnic groups), ${ }^{50}$ and bride price. ${ }^{51}$ However, they also called upon the constitution to ban oppressive customs such as widow inheritance, ${ }^{52}$ depriving widows of their husbands' property, ${ }^{53}$ the marriage of under-aged girls, ${ }^{54}$ female genital mutilation, ${ }^{55}$ stripping women naked and cutting some parts of their bodies with sharp instruments ${ }^{56}$ forcing a woman to sleep with the body of her deceased husband before he is buried, ${ }^{57}$ prohibiting women from eating some types of food, ${ }^{58}$ prohibiting women from owing land, ${ }^{59}$ prohibiting women from exercising their right to freedom of speech, ${ }^{60}$ prohibiting women from inheriting ${ }^{61}$ or owning property, ${ }^{62}$ forced marriages, ${ }^{63}$ prohibiting women from having custody of their children, ${ }^{64}$ denying girls an education, ${ }^{65}$ refund of bride price should the marriage break down, ${ }^{66}$ and all other cultural practices that discriminate against or impair the dignity of women. ${ }^{67}$ The delegates emphasised that the constitutional prohibition of oppressive and discriminatory customary practices would compel the government to adopt different measures to eliminate such practices.

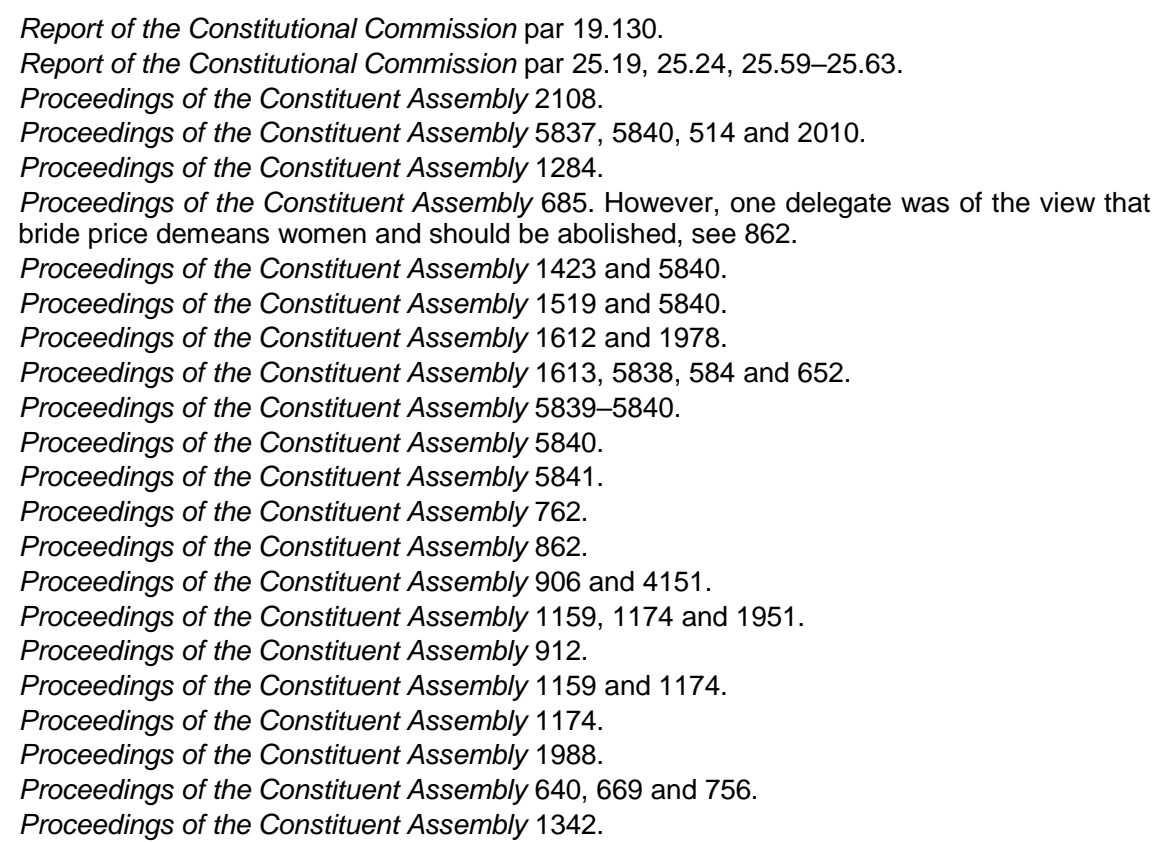


Some delegates argued that apart from a constitutional outlawing of oppressive and discriminatory cultural practices, the government should put in place measures to educate people about the harmful effects of these practices. ${ }^{69}$ However, because "it took centuries of oppressive customs and tradition to reduce the women of this country to the, position of child bearing, free labour" among other practices, "it will take quite some time to totally reverse this". ${ }^{70}$ It was argued that although the State should prohibit oppressive customary practices, it is not its responsibility to create culture. As one delegate put it:

"The State cannot regulate or set up laws that will govern the cultures and customs. True, there are customs and traditions that are repugnant but we all know that culture is dynamic, culture evolves, so are traditions and practices and so on. But if we say that the State will start regulating culture, in other words, the State can set up culture of its own because you have given them the power, but the State has no power to create culture, customs or traditions."

Some delegates argued that there may be a need to legislate some cultural practices because

"[m]ost of the laws we make are a result of long customs and traditions. We only legalise them, we only put them on Statutes. Take the Human Rights, for instance, most of them are the things that are a part of our culture."

\section{Constitutional provisions on customary law and practices}

It is on the basis of the drafting history outlined above that the Constitution was adopted in 1995 with various provisions relevant to customary law. The Ugandan Constitution, including the stated National Objectives and Directive Principles of State Policy, recognises that in Uganda people have different customs. Thus, paragraph (iii) of National Objective III (dealing with national unity and stability) provides that "[e]verything shall be done to promote a culture of cooperation, understanding, appreciation, tolerance and respect for each other's customs, traditions and beliefs". ${ }^{73}$ National Objective XXIV provides for "cultural objectives" and it is to the effect that:

Proceedings of the Constituent Assembly 5841 and 1212.

Proceedings of the Constituent Assembly 398.

Proceedings of the Constituent Assembly 2009. See also 2010-2013.

Proceedings of the Constituent Assembly 4011.

For the legal status of the National Objectives and Directive Principles of State Policy, see Advocates Coalition for Development \& Environment $v$ Attorney General (Constitutional Petition No. 14 of 2011) [2011] UGCC 11 (15 November 2011); Hon Sam Kuteesa v Attorney General (Constitutional Reference No. 54 of 2011) [2012] UGCC 02 (4 April 2012); Fox Odoi - Oywelowo v Attorney General (Constitutional Petition No. 8 of 2003) [2004] UGCC 2 (30 March 2004); Thomas Kwoyelo alias Latoni v Uganda (Const. Pet. No. 036 of 2011(reference)) [2011] UGCC 10 (22 September 2011); Oloka-Onyango v Attorney General (Constitutional Petition No. 08 of 2014) [2014] UGCC 14 (1 August 2014); and Tumuhamye $v$ Nakamya (Civil Suit No. 42 of 2015) [2017] UGHCCD 126 (18 September 2017). 
"[c]ultural and customary values which are consistent with fundamental rights and freedoms, human dignity, democracy and with the Constitution may be developed and incorporated in aspects of Ugandan life. The State shall (i) promote and preserve those cultural values and practices which enhance the dignity and well-being of Ugandans; (ii) encourage the development, preservation and enrichment of all Ugandan languages; (iii) promote the development of a sign language for the deaf; and (iv) encourage the development of a national language or languages."

Although the Constitution recognises customs, this recognition is not unlimited. Customs are only recognised as long as they are not contrary to the Constitution. Thus, Article 2(1) of the Constitution provides that the Constitution is the supreme law of Uganda and, most importantly, Article $2(2)$ is to the effect that "[i]f any other law or any custom is inconsistent with any of the provisions of this Constitution, the Constitution shall prevail, and that other law or custom shall, to the extent of the inconsistency, be void". ${ }^{74}$

The Constitution prohibits discrimination (Article 21) but also obliges the State (Article 32(1)) to "take affirmative action in favour of groups marginalised on the basis of gender, age, disability or any other reason created by history, tradition or custom, for the purpose of redressing imbalances which exist against them". Because Ugandan women have been victims of oppressive customary practices in the past, Article 33 of the Constitution is dedicated to the rights of women generally. However, it also specifically addresses the issue of customary practices. Article 33(5) and (6) is to the effect that:

"(5) Without prejudice to article 32 of this Constitution, women shall have the right to affirmative action for the purpose of redressing the imbalances created by history, tradition or custom. (6) Laws, cultures, customs or traditions which are against the dignity, welfare or interest of women or which undermine their status, are prohibited by this Constitution."

The above outline shows that although customs, and thus customary law, are recognised in Uganda, they are subject to the Constitution. The inclusion of these provisions in the Constitution was informed by Ugandan history, which was characterised by oppressive cultural practices, especially against women. The Constitution on its own does not mean anything unless it is given effect to in practice, which requires legislation to be passed or courts to interpret the relevant provisions of the Constitution and relevant legislation. The challenge is that customary law is not codified and courts have had to assess, in piecemeal fashion, whether certain customary practices are contrary to the Constitution, and especially to the Bill of Rights.

74 See Report of the Constitutional Commission par 28.61: “... it must be clearly provided that the Constitution is superior to all other laws and customs, and that all acts of the executive and other governmental bodies must be consistent with it." See also par 28.63: "It should be enshrined in the Constitution that:- ... (e) If any law or custom does not conform to the Constitution, the Constitution should prevail, and the other law or custom should not apply to the extent that it does not conform to the Constitution." 


\section{COURTS AND OPPRESSIVE CUSTOMARY PRACTICES}

Courts have taken two approaches in an effort to bring an end to oppressive customary practices. The first approach is to declare such practices unconstitutional based on the cases filed by litigants, especially nongovernmental organisations. The second approach is for the courts to declare some customary practices unconstitutional of their own volition. Following the first approach, courts have held that certain cultural or customary practices are contrary to the Constitution generally and to women's rights in particular. These are: the duty of women or their parents to refund bride price at the dissolution of a marriage $;^{75}$ and female genital mutilation (it violates women's rights, the right to freedom from torture or cruel inhuman or degrading treatment and Uganda's international human rights obligations). ${ }^{76}$ This approach is understandable since the High Court, in Lwamasaka Nkonge Prosper (Kinyenyambali) v James Magala Muteweta (Kyana) $)^{77}$ held:

"Customary law, principles and customary/cultural leaders are not unimportant; indeed, they have a significant contribution to make in our unfolding constitutional democracy. Apart from its importance, all customary law and leadership will have to reflect and adjust to the overall changes that have occurred in Uganda's constitutional and legal system. The customs and culture that conflict with the Constitution, especially the Bill of rights or any enacted legislations shall always be challenged in the courts for invalidity. The Constitution is supreme and customary law must comply completely with all constitutional requirements."

Under the second approach, courts have declared the following cultural practices unconstitutional: widow inheritance $;^{79}$ barring widows from inheriting part of the deceased husband's estate, ${ }^{80}$ barring daughters from inheriting part of the deceased father's estate ${ }^{81}$ the custom approving marital rape $;^{82}$ and the custom of kidnapping a woman for the purpose of forcing her to marry her kidnapper. ${ }^{83}$

75 Mifumi (U) Ltd v Attorney General (Constitutional Appeal No. 02 of 2014) [2015] UGSC 13 (6 August 2015); Ochom v Okwap (Civil Appeal No. 11 of 2012) [2014] UGHCCD 66 (7 May 2014).

76 Law \& Advocacy for Women in Uganda v Attorney General (Constitutional Petition No. 8 of 2007) [2010] UGCC 4 (28 July 2010).

77 (Miscellaneous Cause No. 65 of 2015 \& 87 of 2016) [2019] UGHCCD 140 (12 July 2019).

78 Lwamasaka Nkonge Prosper (Kinyenyambali) v James Magala Muteweta (Kyana) supra 8.

79 Ebiju v Echodu (Civil Appeal No. 43 of 2012) [2015] UGHCCD 122 (17 December 2015). See also Nalumansi $v$ Kasande (Civil Appeal No. 010 Of 2015) [2017] UGSC 21 (10 July 2017) (in which the court dealt with $s 30$ of the Succession Act).

80 Ebiju v Echodu supra.

81 Otikor v Anya (Civil Appeal No. 38 of 2012.) [2016] UGHCLD 10 (5 May 2016).

82 Uganda $v$ Yiga Hamidu (Criminal Session Case 005 of 2002) [2004] UGHCCRD 5 (9 February 2004).

83 Uganda v Byarugaba (Criminal Session Case No.361 of 2013) [2017] UGHCCRD 116 (15 August 2017); Uganda v Nakoupuet (Criminal Case No. 109 of 2016) [2019] UGCOMMC 13 (13 February 2019). 
However, in the name of culture, some courts have made statements that approve of some cultural practices and are thus likely to perpetuate discriminatory cultural practices or agitate some human rights activists. These have included a statement that "[i]t should be noted that in many of the African cultures, a [sic] heir is the eldest son unless the son is a rogue." ${ }^{84}$ It could be argued that such a cultural practice could be challenged for infringing women's rights to equality under Article 21 of the Constitution, which prohibits discrimination on many grounds, including gender and sex. In fact there is evidence that this cultural practice is under attack and may soon cease to exist. For example, in Kolya $v K_{0} / y a^{85}$ the deceased, in his will, bequeathed the matrimonial home to his son (the heir). The wife challenged this approach on the ground that she had contributed to the construction of the house and that it was unfair for the deceased to bequeath the house to his son. In upholding the wife's submission, the High Court held that "the deceased exulted the heir above the widow. A culture practice that where the heir inherits matrimonial home denying widows proprietary rights is discriminatory in nature." 86 The Court added that the cultural practice in question was contrary to Articles 21, 31 and 32(2) of the Constitution and to Article 5 of the Convention on the Elimination of All Forms of Discrimination Against Women. ${ }^{87}$ In Uganda $v$ Katerega, ${ }^{88}$ the High Court convicted the accused of defiling his daughter and, in sentencing him to 25 years' imprisonment, observed:

"Before sentence, I call upon all members of society that we should respect our traditions and customs (in Africa) which are unparreled [sic] to other peoples cultures elsewhere in Europe and America. In such places, practices which are abhorred by African cultures like sodomy and homosexuality are freely practised. But even then, Americans and Europeans don't play sexual intercourse with their own children. It is goats and cows and other wild animals that sometimes do so."

Although the Constitution of Uganda does not prohibit discrimination on the ground of sexual orientation, the above observation by the judge may not be taken lightly by some human rights activists who could argue that it is discriminatory. However, this argument is unlikely to succeed because the High Court has been consistent in its view that homosexuality is an offence against morality and culture and that the jurisprudence of the European Court of Human Rights that prohibits discrimination on the basis of sexual orientation is not binding on Ugandan courts. ${ }^{90}$ Another criticism of the court is that it appears to generalise when it held that its views were applicable to Africa as a whole. This approach is not limited to one decision. In an earlier

84 Uganda $v$ Namakula (Criminal Session Case No. 019/2013) [2016] UGHCCRD 146 (15 December 2016) 6.

85 (Civil Suit No. 150 of 2016) [2020] UGHCFD 4 (3 July 2020).

86 Kolya v Kolya supra 7.

87 Ibid.

88 (Criminal Session Case No. 0405 of 2013) [2016] UGHCCRD 1 (13 April 2016).

89 Uganda $v$ Katerega supra 4.

90 Nabagesera v Attorney General (Misc. Cause No. 033 of 2012) [2014] UGHCCD 85 (24 June 2014). In Mubiru Kisingiri v Uganda (HCT-0OCR-CN-O108 - 2015) [2016] UGHCCRD 6 (19 April 2016), it was observed that sodomy is against Ugandan culture, norms and traditions. 
case, the High Court also observed that "it was 'anti African Culture"' for the accused to defile the complainant in her parents' bedroom ${ }^{91}$ and that the "accused is the victim's paternal uncle and by an African culture a parent to her.",92 Such statements could be criticised on the basis that the courts seem to be under the impression that cultural practices in all parts of Africa are similar.

Apart from declaring some customary practices unconstitutional, courts have also held that some customary practices comply with the Constitution and do not violate human rights. One of these practices is the payment of bride price (dowry). ${ }^{93}$ For example, in Wonaku $v$ Makoba, ${ }^{94}$ the High Court, while relying on the jurisprudence of the Supreme Court, held:

"In many communities, the cultural practice of bride price, the payment of a sum of money or property by the prospective son-in-law to the parents of the prospective bride as a condition precedent to a lawful customary marriage, is not barred by the Constitution. It is not per se unconstitutional. The Constitution does not prohibit a voluntary, mutual agreement between a bride and a groom to enter into the bride price arrangement. A man and a woman have the constitutional right to choose the way they wish to get married. It is unconstitutional if the parties are not left free to choose how they want to get married."

Courts have also confirmed the existence and lawfulness of some cultural practices such as the appointment of a customary heir; ${ }^{6}$ the right of the family of someone deceased to bury his or her body according to their cultural practices; ${ }^{97}$ and that the cultural practice of keeping twins in contact is applicable even in cross-border adoption cases. ${ }^{98}$

The above jurisprudence shows that courts are willing to find a cultural practice unconstitutional if it is contrary to any of the provisions of the Constitution. The challenge though is that court judgments may not be read by all those who engage in such cultural practices and these practices could continue unabated, especially in rural areas. This may require legislation to be enacted specifically to address that lacuna.

\section{LEGISLATIVE INTERVENTION}

Various pieces of legislation relate directly or indirectly to customary law or cultural practices. For example, the Equal Opportunities Commission Act ${ }^{99}$ establishes the Equal Opportunities Commission with a mandate to carry out

93 Mifumi (U) Ltd v Attorney General (Constitutional Appeal No. 02 of 2014) [2015] UGSC 13 (6 August 2015).

94 Supra.

95 Wonaku v Makoba supra 3.

96 Ngaaga v Matovu (Civil Case No. 107 of 2003) [2012] UGHC 139 (18 December 2012).

97 Nobert Mao v Attorney General of Uganda (Constitutional Petition No. 9 of 2002) [2003] UGCC 3 (16 March 2003).

98 In Re Victoria Babirye Namutosi (Adoption Cause No.09 of 2017) [2018] UGHCFD 1 (19 January 2018).

99 Equal Opportunities Commission Act 2 of 2007. 
many activities. Some of these activities relate to ensuring that some customs and cultural practices are in line with the Constitution generally and, in particular, that such practices are not invoked to introduce or perpetuate inequality. Thus, the functions of the Equal Opportunities Commission are to:

"monitor, evaluate and ensure that policies, laws, plans, programs, activities, practices, traditions, cultures, usages and customs of [among others] ... social and cultural communities, are compliant with equal opportunities and affirmative action in favour of groups marginalized on the basis of sex, race, colour, ethnic origin, tribe, creed, religion, social or economic standing, political opinion, disability, gender, age or any other reason created by history, tradition or custom.

The Commission is also empowered to "examine any law, proposed law, policy, culture, tradition, usage, custom or plan which is likely to have effect of nullifying or impairing equal opportunities to persons in employment or enjoyment of human rights" 101 and to "prepare and publish, guidelines for implementation of equal opportunities and the avoidance of acts, practices, usage, customs, tradition or cultures that undermine equal opportunities."102 The Commission is also empowered to:

"rectify, settle or remedy any act, omission, circumstance, practice, tradition, culture, usage or custom that is found to constitute discrimination, marginalisation or which otherwise undermines equal opportunities through mediation, conciliation, negotiation, settlement or other dispute resolution mechanism.

\section{It is also empowered to:}

"hear and determine complaints by any person against any action, practice, usage, plan, policy programme, tradition, culture or custom followed by any organ, body, business organisation, institution or person which amounts to discrimination, marginalization or undermines equal opportunities."

Although the Commission has handled many cases, ${ }^{105}$ it is yet to deal with a matter that involves the relationship between a customary practice and access to equal opportunities.

Another piece of legislation that deals with oppressive customary practices is the Prohibition of Female Genital Mutilation Act, 2010. This Act prohibits female genital mutilation and section 10 of the Act provides that "[a]ny culture, custom, ritual, tradition, religion or any other non-therapeutic reason shall not be a defence under this Act." However, media reports indicate that despite the fact that female genital mutilation is an offence, it is still being practised in some parts of Uganda. ${ }^{106}$

$100 \mathrm{~S} 14(1)$.

$01 \mathrm{~S} 14(2)(b)$

$102 \mathrm{~S} 14(2)(f)$.

$103 \mathrm{~S} 14(3)$.

$104 \mathrm{~S} 14(4)$

105 See generally (for some of the decisions the Commission has published on the website) http://www.eoc.go.ug/publications-downloads (accessed 2020-02-09).

106 See for e.g., Monitor Reporter "How Culture Prepares Women to Defy FGM Law" (28 January 2019) https://www.monitor.co.ug/News/National/How-culture-prepares-women- 
Section 46(1) of the Children Act ${ }^{107}$ provides that "[a] person who is not a citizen of Uganda may in exceptional circumstances adopt a Ugandan child, if he or she - (a) has stayed in Uganda for at least three years." The rationale behind section 46(1)(a) was explained in the High Court case of $R e$ Nakawesa, Namanda \& Katongole (infants), ${ }^{108}$ where it was observed:

"[t]he above requirement applies only to foreign nationals who are not members of an indigenous tribe in Uganda; and have not lived in Uganda for at least 3 years. This is so because that group of foreign nationals is not conversant with the social setting and cultural norms of Uganda. Therefore, they require at least a 3 years' stay in Uganda to get an understanding of the above matters so that the subsequent adoption of children from the Ugandan setting might not be an onerous task to them."

The above are some of the pieces of legislation enacted to combat oppressive cultural practices. Another law which, if it is passed, will prohibit some customary practices is the Marriage and Divorce Bill. ${ }^{110}$ This Bill prohibits some cultural practices such as widow inheritance (clause 13), forced marriages (clause 16) and depriving widows of their property (clause 123).

\section{COURTS WITH JURISDICTION OVER CUSTOMARY LAW ISSUES}

Because customary law forms part of the Ugandan legal order, it is important for it to be enforceable and that there be a system to resolve disputes arising out of its enforcement or implementation. This is why some Constituent Assembly delegates believed that wherever there is a dispute between people regarding a question of customary law, they should refer it to courts for resolution. ${ }^{111}$ Parliament has enacted legislation stipulating that courts have jurisdiction over customary law matters. In Uganda, different courts have different jurisdiction. Thus, Article 129 of the Constitution provides as follows:

"(1) The judicial power of Uganda shall be exercised by the courts of judicature which shall consist of - (a) the Supreme Court of Uganda; (b) the Court of Appeal of Uganda; (c) the High Court of Uganda; and (d) such subordinate courts as Parliament may by law establish, including qadhis' courts for marriage, divorce, inheritance of property and guardianship, as may be prescribed by Parliament. (2) The Supreme Court, the Court of Appeal and the High Court of Uganda shall be superior courts of record and shall each have all the powers of such a court. (3) Subject to the provisions of this

\footnotetext{
Kween-defy-FGM-law/688334-4960544-5cc2pc/index.html; Monitor Correspondent "Police Arrest 19 for Aiding Female Circumcision" (23 January 2019) https://www.monitor.co.ug/ News/National/Police-arrest-19-for-aiding-female-circumcision/688334-4946618-Imbi2l /index.html (accessed 2020-02-09).

107 Children Act Chapter 59.

108 Re Nakawesa, Namanda \& Katongole (infants) (Adoption Cause No 164 of 2011) [2011] UGHC 107 (2 August 2011).

109 Re Nakawesa, Namanda \& Katongole (infants) supra 2.

110 Marriage and Divorce Bill, 2009.

111 Proceedings of the Constituent Assembly 4009.
} 
Constitution, Parliament may make provision for the jurisdiction and procedure of the courts."

Because many customary law issues are at local level and each ethnic group has its own unique cultural practices, Parliament thought it wise to confer jurisdiction over customary law matters to local courts. This was done by enacting the local council courts on the basis of Article 129(1)(d) of the Constitution. Thus, section 10(1)(b) of the Local Council Courts Act, 2006 provides:

"Subject to the provisions of this Act and of any other written law, every local council court shall have jurisdiction for the trial and determination of causes and matters of a civil nature governed only by customary law specified in the Third Schedule.

According to the Third Schedule to the Act, local council courts have jurisdiction with regard to the following customary law matters: "(a) disputes in respect of land held under customary tenure; (b) disputes concerning marriage, marital status, separation, divorce or the parentage of children; (c) disputes relating to the identity of a customary heir; (d) customary bailment." 113 Section 32 of the Act provides for the right of appeal against the decisions of local council courts. Through the appeal process, customary law issues are also dealt with by magistrates' courts and the courts of record (the High Court, the Court of Appeal and the Supreme Court). However, as the above case law has illustrated, courts of record have also dealt with customary law questions when they are part of the issues that these courts have been called upon to resolve.

Local council courts are presided over by lay persons and are not courts of record although they are expected to keep a record of their decisions. ${ }^{114}$ The jurisdiction of local council courts in customary law matters has been emphasised by the High Court. ${ }^{115}$ Practice from Uganda shows that some local council courts have exercised that jurisdiction in cases such as determining ownership in customary land matters ${ }^{116}$ and trespass on

112 Regulation 26(g) of the Local Council Courts Regulations, 2007 provides that "[e]very court shall have jurisdiction for the trial and determination of the following cases or matters 'civil disputes governed by customary law- disputes in respect of land held under customary tenure; disputes concerning marriage, marital status, separation, divorce or the parentage of children; disputes relating to the identity of a customary heir; customary bailment."'

113 These courts had similar jurisdiction even before 2006. See Zaidi Ziwa v Gregory Kayita Senvuma (Civil Suit No. 164 of 1993) [1999] UGHC 8 (31 May 1999); Ntalo George v Babirye Edinansi (Civil Revision No. 005 of 2006) [2009] UGHC 209 (25 June 2009); Munobwa Muhamed v Uganda Muslim Supreme Council (Civil Revision No. 1 of 2006) [2010] UGHC 121 (26 August 2010). Before 2006, local council officials had immunity from prosecution for anything done in the course of their duties (they enjoyed judicial privilege), see Angulu George v Republic of Uganda (Civil App. No. 8 of 2007) [2008] UGHC 94 (29 August 2008).

114 Barara v Nyakamaga (High Court Civil Revision 003/2008) [2012] UGHC 46 (13 March 2012).

115 Mutonyi Margaret Wakyala v Tito Wakyala (HCT-04-CV-CR-0007-2011) [2011] UGHC 117 (15 August 2011); Busingye Jamiya v Mwebaze Abdu (HCT-05-CV-CR-0033-2011) [2012] UGHC 68 (18 April 2012).

116 Dudu v Mwalimu Juma (Civil Revision No. 0003 OF 2015) [2016] UGHCLD 7 (14 July 2016); Kemish v Dima (Miscellaneous Civil Application No. 0016 of 2015) [2017] UGHCLD 
customary land. ${ }^{117}$ Local court officials enjoy immunity from prosecution for anything they have done in the course of their duties. ${ }^{118}$ The High Court held that the jurisdiction of local council courts does not extend to land that is not customary land. ${ }^{119}$ In some cases, while dealing with customary land matters, local council courts have conducted their proceedings irregularly and their decisions have had to be set aside by the High Court. ${ }^{120}$ Because of illiteracy, some people are not aware that local council courts have jurisdiction over customary land matters and they refer disputes over customary land to politicians. ${ }^{121}$ This means that there is a need for the local council officials to be trained in these matters and for people to be informed about the jurisdiction of local council courts. In some cases, people have disobeyed the orders of local council courts to vacate customary land on which the courts found them to have trespassed and they have had to ask politicians to intervene on their behalf. ${ }^{122}$

Even before the adoption of the 1995 Constitution, the jurisdiction of the local council courts included customary law matters. ${ }^{123}$ However, apart from local council courts and magistrates' courts, customary law is also enforced by informal courts. The problem is that these informal courts are not recognised by the Constitution because, during the making of the Constitution, submissions for such courts to be recognised in the Constitution were unsuccessful. The Constitutional Commission observed:

"[a]Ithough the magistrates and RC courts ${ }^{124}$ dispose of many disputes which may arise out of customary law in Uganda, many such disputes are solved by informal courts, usually clan and family courts that deal with disputes between individuals. Some views have suggested that such courts should be recognised by law so that their decisions can be enforced. We are of the view that this should not normally be necessary because anyone dissatisfied with

56 (27 April 2017); Uganda Telecom Limited v Adratere Oreste (Miscellaneous Civil Application No. 0021 of 2015) [2017] UGHCLD 9 (20 July 2017); Wambewo $v$ Mazelele (HCT-04-CV-MA-0171-2011) [2012] UGHC 173 (16 August 2012); Onzia v Shaban Fadul (Civil Appeal No. 0019 of 2013) [2017] UGHCLD 82 (15 June 2017); Dubo v Minduni (Civil Revision No. 0001 of 2017) [2017] UGHCLD 54 (27 April 2017); Odyeki v Yokonani (Civil Appeal No. 0009 of 2017) [2018] UGHCCD 50 (11 October 2018).

117 Lubwama v Muganzilwazza Growers Co-operative Society (Civil Appeal No.018 of 2016) [2017] UGHCLD 52 (2 May 2017); Kisame Samson alias Sseruwagi v Ali Kiyinikibi (Civil Revision No. 4 of 2008) [2010] UGHC 21 (21 February 2010); Kurusumu v Masereka (HCT01-LD-CA 29 of 2014) [2016] UGHCLD 52 (20 December 2016).

118 Muwisa v Biguyi (HCT-01-LD-CA-0041 of 2013) [2016] UGHCLD 50 (20 December 2016).

119 Alanyo v Angut (Civil Appeal No HCT-02 CV CA 0025/2009) [2014] UGHCLD 60 (22 August 2014); Administrator General suing Through Grace Nataya v Sunday Edward Mukol (High Court Civil Suit No. 211 of 2002) (High Court Civil Suit No. 211 of 2002) [2008] UGHC 32 (22 March 2008).

120 Kirangi v Karimunda (HCT Civil Revision No. 06 of 2011) [2012] UGHC 191 (21 September 2012).

121 Sinnabulya $v$ Sekibaala (Civil Appeal No. 6 of 2005) [2013] UGHCLD 23 (12 March 2013).

122 Okello v Uganda (Criminal Appeal No. 0035/2013) [2014] UGHCCRD 37 (22 August 2014).

123 Resistance Committee Courts had jurisdiction over, inter alia, "[c]ustomary law matters such as disputes on land, marital status of women, paternity of children, identity of customary heirs, impregnating of girls under eighteen years of age, elopement with girls under eighteen years and customary bailment". See Report of the Constitutional Commission par 17.18(b)

124 Resistance Committee Courts which would later become local council courts. 
the decision of such courts can commence proceedings in the $\mathrm{RC}_{1}$ courts which have power to deal with a wide range of customary law matters.

The refusal to acknowledge informal courts means that many customary law disputes are being resolved informally. Practice from Uganda shows that clan courts have dealt with some customary matters such as land, ${ }^{126}$ bride price, ${ }^{127}$ and marriage disputes. ${ }^{128}$ However, they also settle matters that have nothing do to with customary law such as defilement cases. ${ }^{129}$ In determining a sentence to impose on a person convicted of an offence, courts will also consider, inter alia, his or her cultural beliefs and background. ${ }^{130}$

\section{CONCLUSION}

In this article, the author has demonstrated the measures being taken in Uganda to abolish oppressive and discriminatory cultural practices. Two general approaches have been followed in this regard - namely, a general prohibition of such practices by the Constitution, and also specific prohibitions. With regards to the general prohibition, the Constitution prohibits oppressive customary practices; and courts, relying on the Constitution, have found such practices to be unconstitutional. With regard to specific prohibition, legislation has been enacted to criminalise some cultural practices such as female genital mutilation. Nevertheless, some prohibited practices continue to be practised in Uganda.

It is submitted that the government should intensify educational campaigns to ensure that those who engage in such practices are sensitised about the law and also the disadvantages of these practices. Alternative ways in which some cultural practices could be practised without violating the Constitution must also be considered. In cases where practices are criminalised - for example, female genital mutilation - effective policing and prosecution could deter some from engaging in these.

125 Report of the Constitutional Commission par 17.157. See also par 18.35.

126 Emuron "Former Soldier Throws Grenade in Land Meeting, Gets Killed" (22 January 2019) https://www.monitor.co.ug/News/National/Former-soldier-throws-grenade-land-meetinggets-killed/688334-4945264-11dqhqy/index.html (accessed 2020-02-09).

127 Ocungi "Acholi to Draft a Bylaw on Bride Price, Says Chief" (1 January 2019) https://www.monitor.co.ug/News/National/Acholi-to-draft-a-bylaw-on-bride-price/6883344916522-141ppat/index.html; Otwii "Lango Men Forced to 'Marry' the Dead" (12 December 2018) https://www.monitor.co.ug/News/National/Lango-men-forced--marry--dead/6883344891394-ha83rt/index.html (accessed 2020-02-09).

128 Owich and Ocungi "Traditional Leaders on the Spot Over Increasing Torture" (3 October 2018) https://www.monitor.co.ug/News/National/Traditional-leaders-spot-over-increasingtorture/688334-4788378-wfalk6z/index.html (accessed 2020-02-09).

129 Mukooli "In Bududa, Parents Prefer Clan Heads to Resolve Defilement Cases" (28 August 2018) https://www.monitor.co.ug/News/National/In-Bududa-parents-prefer-clan-headsresolve-defilement-cases/688334-4731612-vdev20z/index.html (accessed 2020-02-09).

130 Uganda v Dimba (Criminal Case No. 0089 of 2014) [2017] UGHCCRD 5 (16 January 2017); Gwolo Jackson v Uganda (Criminal Appeal No. 0014 of 2017) [2017] UGHCCRD 118 (14 September 2017). 